\title{
Islamic work ethics in management performance perspectives: Conceptualization and value internalization
}

\author{
J. Hutasuhut, A.R. Syamsuri \& A. Saragih \\ Universitas Muslim Nusantara Al Washliyah Medan, Indonesia \\ S. Sarkum* \\ Universitas Labuhan Batu, Rantauprapat, Indonesia
}

\begin{abstract}
Islamic work ethics can be understood as a set of values or belief systems based on the Qur'an and the Hadith regarding work and hard work. The purpose of Islamic work ethics is to align the organizational goals with employees' goals so that they can run the business well. With such attitudes and behaviors, it is expected that companies or organizations be able to adapt and respond to various changes in a business environment that are changing rapidly. The benefits of Islamic work ethics are expected to be a requirement for employees to work so they will be safe in both the world and hereafter according to the Islamic values which are determined in the Qur'an and Al-Hadith. Workers with the Islamic work ethic will be more motivated to produce optimal performance hope that they will get halal sustenance and will avoid disapproval from Allah SWT.
\end{abstract}

Keywords: Islamic work ethics, halal, management, performance

\section{INTRODUCTION}

Etymologically, ethics and morals both mean customs. Ethics comes from the ancient Greek 'ethos' and plural 'taetha', while morals comes from the Greek ' $m o s$ ' and the plural 'mores' (Bertens 2007). Ethics deals with questions about how people will behave towards each other (Hidayah 2018). Ethics as a reflection is moral thinking which means that humans must think about what must be done or not to be done. Philosophically, ethics has a broad meaning as a study of morality. It also encompasses several functions. First, descriptive ethics describes moral experience to determine the motivation and purpose of an action in human behavior. Second, normative ethics attempts to explain why humans act as they do and what principles emerge in humans' lives. Third, metaethics attempts to give meaning, terms, and language for use in ethical discussions and give the ways of thinking used to justify ethical agreements (Nawatmi 2010). The organization cannot answer many human resource problems through rationality, such as by local intellectuals to western management. This phenomenon is seen in the results of studies that continue to roll from progressive Islamic thinkers in countries with a Muslim majority, such as Indonesia. The individualist, materialist, secular nature of western management and manipulative practices have reinforced the argument that Muslims must not forget the religious values regulated by Allah and the Messenger of Allah. Islam as a religion that brings the concept of rahmatanlilalamin, and provides guidelines for people, including how their work organizes ethics in an organization (Kusuma \& Ralmat 2018).

In relation to ethics, Islam suggests that every individual who works will tell him/her about what he/she has done. Islam also explains halal and haram. Ridwan (2019) explains that, in Islamic Sharia, halal is the opposite of haram. Conducting haram will incur punishment and doing halal

${ }^{*}$ Corresponding author 
will be rewarded. Allah is all-knowing and all-compassionate (Kurniawan 2019). About the rules of working in Islam, mankind is commanded by God to always do beneficial work to oneself and others (Ali and Al-Owaihan). According to this explanation, the quality of human resources is not determined only from the knowledge of science and technology but also from the spiritual dimension of faith and taqwa through the dimension of the Islamic Work Ethic accompanied by a halal understanding or through the ordered teachings of Islam. Furthermore, by knowing the dimensions of the work ethic according to halal principles, an employee will have more spiritual responsibility towards all the resources of the organization used to achieve optimal performance. Effective management performance is one way to conduct an activity to be better and develop. Therefore, to practice management performance more effectively, normative rules are needed, containing a system of values and moral principles that are guidelines for employees in conducting their work duties. Aggregation of employee ethical behavior becomes a work ethic description to be applied. Islamic work ethics can be a part that can affect an employee's involvement in doing their work. According to Ali and Al-Owaihan (2008), Islamic work ethic is an orientation that shapes and influences the involvement and participation of its adherents in the workplace. Islamic work ethics enhance selfinterest economically, socially, and psychologically, maintain social prestige, advance society's welfare, and reaffirm faith. The initial concept is derived from the al-Qur'an and the Sunnah.

In modern organizations nowadays, the Islamic work ethic has become a trend to be studied in-depth terms. The main factor is the attractions because there are many studies that prove that Islamic work ethics have a significant influence on employee performance. With this assumption, Islamic work ethics has potential to be used as a solution to mitigating performance problems. Some studies that support this assumption include research conducted by Hutasuhut (2019). He explored the influence of Islamic work ethics on the performance of lecturers at the Muslim Nusantara University of Al-Washliyah Medan. Participants involved were 47 tenured lecturers at the university. The results showed that an Islamic work ethics had a positive effect on working performance. It also states that Islamic work ethics have a close relationship with lecturer performance (Hutasuhut 2019). Lecturers as professional educators cannot just have skills, knowledge, and abilities but must have an Islamic work ethic to produce a more meaningful performance to the required standards.

Imam et al. (2013) analyzed features related to the employees' workings in the corporate sector. In this research, Siddiqui et al. (2019) consider religious values and human life in society and other aspects of life. Islam provides the rules of human life and the basic rules of human life. This study showed two main constructions of Islamic ethics: Islamic recruitment and selection, the Islamic compensation system and employee performance were used as dependent variables. Researchers used 100 employees from the Islamic Bank in Karachi, Pakistan. According to Siddiqui et al. (2019), although many studies focus on ethics in the workplace, ethics still becomes the most discussed matter in recent years. This is due to the continuation of unethical cases in organizations such as corruption, fraud, sexual harassment, and other unethical behavior. Abdi et al. (2014) used a random sampling method. Data was collected using a questionnaire distributed to 40 staff and lecturers at Insaniah University, Kedah. The first part of the questionnaire covered the demographic profile of the respondents, while the second part examined respondents' level of agreement on questions of Islamic work ethics, job performance, and organizational commitment items. The results show that job performance was significantly related to Islamic work ethics. On the other hand, the organizational commitment was not significantly related to Islamic work ethics.

The study conducted by Abbasi et al. (2012) investigated the influence of Islamic work ethics toward organizational learning, innovation, and performance. This research was conducted in the service industry in Pakistan to provide insight into how far the application of Islamic work ethics in business organizations is applied in Pakistan, especially in manufacturing. In this study, data was collected from 240 industrial service employees. The selected districts for data collection are Gujrat, Gujranwala, Sialkot, Lahore and Wazirabad. The main factory is in Gujrat, the head office in Lahore. The results support the opinion that Islamic work ethics in business organizations increase learning, innovation, and organizational performance.

Research conducted by Rohman et al. (2010) that explored the influence of the Islamic work ethic in work such as job satisfaction, organizational commitment and intention using a sample of 49 
employees from 10 Islamic microfinance institutions in Demak Regency, Central Java, Indonesia, found that the Islamic work ethic has a positive effect on both job satisfaction and organizational commitment. Ibrahim (2018) conducted a study on the effect of Islamic work ethics on Muslim employees' efficiency in multinational companies. Research observations analyzed the potential and actual impact of Islamic work ethics in multinational corporations' environments by showing that religion does not significantly influence efficiency, but its internal effects such as internal and interpersonal conflicts with types of corporate activities can be intensified. In fact, this effect will differ based on the division of each employee. For example, when Muslims' religious orientation increases, their activities, according to the type of product or service provided, in the marketing sector can be affected.

Adisi (2014) explored the effect of job satisfaction in accountant performance and the impact of interactions between Islamic work ethics and job satisfaction to maximize accountant performance in the Islamic financial industry in Indonesia. The research instrument used to collect primary data was a questionnaire. Regression analysis was used to test the hypotheses. His study revealed that job satisfaction cannot affect the performance of accountants. He also unveiled that the interaction between Islamic work ethics with job satisfaction can maximize the performance of accountants. Amilin's (2016) efforts to maintain workers' level of performance excellence have been widely discussed, but practitioners still face difficulties, especially in Muslim countries. This is due to complex human behavior and many other factors, such as work stress and dissatisfaction. Although there is a lot of research about ethics has been done, both in an Islamic perspective or a general perspective, there is a lack of studies that investigate the impact of Islamic religious awareness in the workplace. Thus, in response to the impact of Islamic religiosity and Islamic work ethics in improving and maintaining performance, this research is presented, discussed, and investigated empirically for possible implications between Islamic religiosity, Islamic work ethics and performance.

Zahraha et al. (2016) discussed the issue of the work ethic with the rationale of the growing popularity of religion when Max Weber developed the theory of Protestant Work Ethics (PWE), which was then able to strengthen the Western economy through its ideology of capitalism. In his work, he claims that only Protestant Christians can accelerate and improve the economy, while other religions cannot do the same acceleration. Although many scholars reject the claim, the backwardness of many Islamic countries, ethically and economically, has raised many questions about Islam's teaching about work activities. Therefore, this study explores the concept of work ethic from an Islamic perspective, specifically annulling the concepts, principles, dimensions, and values of Islamic Work Ethics (IWE) to be operationalized into daily practice. This will also reveal the truth of the verses of the Qur'an and Hadith, which discuss the concept of work ethics in Islam. If properly operationalized, this can bridge the gap between IWE theory and the reality of economic development in Islamic countries. Obedience will affect economic development in Islamic countries, bringing happy human life in this world and in the hereafter.

\section{ISLAMIC WORK ETHICS}

Irham (2012) explains that work ethics or work ethos in Islam are the values contained in al-Qur'an and al-Sunnah about 'work', which are used as a source of inspiration and motivation by every Muslim to do their work activities in various fields of life. The way they understand, live and practice the values of the al-Qur'an and al-Sunnah about the motivation to work is what shapes the work ethic of Islam. Sono et al. (2019) argues that the Islamic work ethos or Islamic work ethic is a personal attitude that creates a very deep conviction that work is not only to glorify himself and reveal his humanity, but also as a manifestation of pious deeds and therefore has a very noble worship value. Islam is a syumuliyah religion (perfect in terms of teachings) in the sense of regulating the entire joints of human life, including in working as part of the caliph on earth. This is explained implicitly in the Qur'an. Amilin (2016) also discussed are the Islamic work ethics which are based on two dimensions, namely the ukhrawi and worldly dimensions. In the $u k h w a r i$ dimension, Syari'ah emphasizes the importance of intention, which is solely to get virtue from 
God. Work based on Syari'ah principles not only show the nature of Muslims but also elevates his dignity as a trustworthy servant of Allah. Theoretically, syari'ah teaches the concept of ihsan, which means doing perfect work, and itqon, which means a very earnest, accurate, and perfect learning process.

\section{PARAMETERS OF ISLAMIC WORK ETHICS}

Ghozali (2018) explains that the construct of Islamic work ethics was built from several indicators, such as good activity, usefulness, working towards perfection, working better, working together, optimal effort, competing, helping time, being honest, trustworthy, smart, and tabligh. Islamic Work emphasizes intentions over the result. Jufrizen and Parlindungan (2016) and Ali and Owaihan (2008) contend that Islamic work ethics parameters are pursuing legitimate business, earned wealth, quality of work, wages, reliance on self, monopoly, bribery, deeds and intention, transparency, greed, and generosity.

\section{FUNCTION AND PURPOSE OF ISLAMIC WORK ETHICS}

Islamic work ethics are a motivating factor for a person in doing his job well because the work is part of worship. The motivation that comes from within individuals, not from external rewards, is called intrinsic motivation. Islamic work ethics gives meaning to the work we do, that work in the world is one of the determinants of happiness in the hereafter. With these beliefs and awareness, a person's motivation will be greater for doing work even without any incentives (Amaliah et al., 2013). Some jobs will get different treatment depending on how a person sees and believes in his work. Allah Almighty has ordered His people that all their works will be seen by Allah, His Messenger, and those who believe. Someone who has a high work ethic will certainly not feel comfortable if they are not working for several days. In Islam, faith demands real proof through charity, and charity is good deed work. Then, a true Muslim's work ethic will bring up the muhajadah that is serious in realizing his ideals. As a set of positive behaviors at work that comes from beliefs, work ethics can be a driving force.

Hidayat (2015) also corroborates this assertion, as explained in surah al-Dzariyat: 51 . The purpose is normatively derived from the Islamic faith and the true mission of life that man and other beings are created for is "to worship the creator that is Allah SWT." That goal is essentially transcendental because it is limited to the individual's worldly life and life after this world. In achieving these goals, ethical rules are needed to ensure that efforts that realize both the people's objectives and operative goals are always on the right path.

\section{WORK MANAGEMENT}

Aprida (2018) stated that the concept of performance management is an idea that employees must perform their duties or work in accordance with established standards. According to halal philosophy, this concept is also explained in Islam. Good and quality workers will strive to increase their achievement by giving full commitment to the work done. Gruman (2011) also stated that quality workers would also set objectives that they believe will positively impact the organization in a vibrant work atmosphere.

Performance management is a term widely used in human resources and has a special meaning related to the review and management of individual performance. Human resource management plays an essential role in helping organizations obtain and maintain competitiveness compared to high-performance work systems (Idris 2019). Ochurub et al. (2012) suggest that performance management is the ongoing process of identifying, measuring, and developing individual and team performance and aligning their performance with the strategic objectives of the organization. 
Syamsuri et al. (2019) stated that performance management is a comprehensive process related to performance. This reflects the entity's approach to performance and includes subprocesses such as strategy definition, strategy implementation, training, and performance measurement.

\section{CONCLUSION}

Islam regards humans as creatures created by Allah to carry out the mandate of doing worship for their provisions both in this world and in the hereafter. In the context of performance management between the company and employees as leaders and employees of the Islamic kin gdom, human beings must have a high work ethic in carrying out all the mandates they receive to achieve the pleasure of Allah. Islamic work ethic is the work behavior of an employee in accordance with what is ordered and forbidden by Allah SWT as written in the Qur'an and Hadith. "Work for you, so Allah and his messenger and the believers see your work as if you were going to live forever." Islamic work ethics can also be understood as a set of values or belief systems based on the Qur'an and Hadith regarding work and hard work. Islamic work ethics can have a good impact on employee behavior at work because it can provide a stimulus for positive work attitudes. This matter becomes the principle that a Muslim's aim in working is to seek the pleasure of Allah SWT and get the virtue of quality and wisdom from the results obtained.

\section{REFERENCES}

Abbasi A.S., Mir G.M. \& Hussain M. 2012. Islamic Work Ethics:How It Affects Organizational Learning, Innovation \& Performance. Actual Problems of Economics, 12, 471-478.

Abdi M. F., Nor S.F.D.W.M. \& Radz. Md.N.Z. 2014. The Impact of Islamic Work Ethics on Job Performance and Organizational Commitment, Proceedings of 5th Asia-Pacific Business Research Conference 17-18 February, Hotel Istana, Kuala Lumpur, Malaysia, ISBN: 978-1-922069-44-3.

Adisi M. 2014. The Effect of Islamic Work Ethics on The Performance of Muslim Employees of Marketing Sector In Multinational Companies, 3, 31-40, International Journal of Organizational Leadership.

Afrida. 2018. Hakikat Manusia dalam Perspektif Al-Qur'an. 16(2), 54-59, Jurnal AL-QISTHU: Kajian IlmuIlmu Hukum, IAIN Kerinci.

Amaliah I., Julia A. \& Riani W. 2013. Pengaruh Nilai Islam terhadap Kinerja, 29(2), 165-174, MIMBAR.

Amilin A. 2016. Measuring the Correlation of Job Satisfaction with Accountants Performance: The Role of Islamic Work Ethics as a Moderator, European Research Studies Volume XIX, Issue 4, $217-232$.

Ali A. J., \& Al-Owaihan A. 2008. Islamic work ethic: a critical review”, Cross Cultural Management: An International Journal, Vol. 15, No. 1, pp. 5-19.

Bertens K. 2007. Etika. Gramedia Pustaka Utama, Jakarta.

Ghozali M. 2018. Konsep Profesionalisme terhadap Pekerjaan dalam Perspektif Islam, Proceedings of the 5th International Conference on Management and Muamalah.

Gruman J. A. \& Saks A. M. 2011. Performance management and employee engagement. Human Resource Management Review, 21(2), 123-136. 2011,

Hidayah N. 2018. Analisis Etika Kerja Islam dan Etika Penggunaan Komputer terhadap Ketidaksesuaian Penggunaan Komputer oleh Pengguna Teknologi Informasi di UMKM Kabupaten Bantul, 8(1), 59-73, Jurnal EkonomiSyariah Indonesia.

Hidayat S. \& Tjahjono H.K. 2015. Peran EtikaKerja Islam dalam Mempengaruhi Motivasi Intrinsik, Kepuasan Kerja dan dampaknya terhadap Komitmen Organisasional (Studi Empiris pada Pondok Pesantren Modern di Banten). Jurnal Akuntansi dan Manajemen, Universitas PGRI Yogyakarta, 625-637, upy.ac.id

Hutasuhut J. 2019. Pengaruh Etika Kerja Islami terhadap Kinerja Dosen, 2(2), 1-3, Jurnal BEST: Biology Education, Scientific \& Technology.

Ibrahim A. 2018. Islamic Work Ethics and Economic Development in Islamic Countries: Bridging Between Theory and Reality, 2, 43-50, Proceeding of 2nd International Conference on Empowering Moslem Society in Digital Era, ISSN 2622-5840.

Imam A., Abbasi A.S, \& Muneer S. 2013. The Impact of Islamic Work Ethics on Employee Performance: Testing Two Models of Personality X and Personality Y. 25(3), 611-617, Sci.Int (Lahore). 
Idris M., Zakaria W.F.A.W., Long A.S. \& Salleh N. 2019. Kualiti Kerja dalam Organisasi: Tinjauan dari Perspektif Pengurusan Islam Work Quality in Organization: An Islamic Management Perspective, 15, International Journal of Islamic Thought.

Irham M. 2012. Etos Kerja dalam Perspektif Islam. 14(1), 11-24, Jurnal: Substantia. Jufrizen \& Parlindungan R. 2016. Model Pengembangan Etika Kerja Berbasis Islam Pada.

Perguruan Tinggi Islam Swasta di Kota Medan. I (1), 120-136. Jurnal Ilmiah Maksitek.

Kusuma B. M. A. \& Rahmat I. 2018. Mozaik Islam dan Manajemen Kinerja, Yogyakarta, Samudra Biru.

Kurniawan R. 2019. Urgensi Bekerja dalam Al-Qur'an, 3(1), 42-67, Jurnal Transformatif: Islamic Studies, IAIN Palangkaraya.

Nawatmi S. 2010. Etika Bisnis dalam Perspektif Islam, 9(1), 50-58, Fokus Ekonomi (FE).

Ochurub M., Bussin M. \& Goosen X. 2012. Organisational readiness for introducing a performance management system. SA Journal of Human Resource Management, 10(1), 1-11.

Ridwan M. 2019. Nilai Filosofi Halal dalam Ekonomi Syariah. 3(1), 14-29, Profit:Jurnal Kajian Ekonomi dan Perbankan, STAIN Kudus.

Rokhman W. 2010. The effect of Islamic Work Ethics on Work Outcomes. EJBO Electronic Journal of Business Ethics and Organization Studies. 15(1), 21-27.

Siddiqui N.U.H., Hameed S. Sattar R. A. \& Eneizan B. 2019. Islamic Work Ethics Impact on Employee Performance, 3(8), 1-7, International Journal of Academic Multidisciplinary Research (IJAMR).

Sono N. H., Hakim L. \& Oktaviani L. 2019. Etos Kerja Islam sebagai upaya meningkatkan Kinerja. 411-420, e-Proceeding. https://jurnal.unej.ac.id/index.php/prosiding/article/view/6687

Syamsuri A.R., Halim A. \& Sarkum S. 2019. Organizational Transformation:A Reviews of The Literature. Int. Journal of Scientific \& Technology Research, 8(8).

Zahraha N., Norasyikin S., Rani S.H. \& Rani B. A. 2016. The Relationship between Islamic Religiosity, Islamic Work Ethics and Job Performance, 710-716, The European Proceedings of Social \& Behavioural Sciences Ep SBS. 